\title{
Potencial evocado miogênico vestibular (Vemp): avaliação das respostas em indivíduos normais****
}

\author{
Vestibular evoked myogenic potential (Vemp): evaluation of \\ responses in normal subjects
}

\author{
Lilian Felipe* \\ Marco Aurélio Rocha Santos** \\ Denise Utsch Gonçalves***
}

*Fonoaudióloga. Doutoranda em Ciências da Saúde - Infectologia e Medicina Tropical.

Fonoaudióloga do Serviço de Atenção

à Saúde Auditiva do Hospital das Clínicas da Universidade Federal de Minas Gerais. Endereço para correspondência:

Rua Euclásio, 426 - Apto 102 - Belo Horizonte - MG - CEP 30260-220 (lilianfelipe@hotmail.com)

**Médico Otorrinolaringologista. Doutor em Ciências pelo Programa de Pós Graduação em

Otorrinolaringologia e Cirurgia de Cabeça e Pescoço da Universidade Federal de São Paulo. Professor do Departamento de Oftalmologia e Otorrinolaringologia da Faculdade de Medicina da Universidade Federal de Minas Gerais.

***Médica Otorrinolaringologista. Professora Adjunto do Departamento de Oftalmologia e Otorrinolaringologia da Faculdade de Medicina da

Universidade Federal de Minas Gerais. Doutora em Medicina pelo Programa de Pós-Graduação em Ciências da Saúde: Infectologia e Medicina Tropical.

\begin{abstract}
Background: the Vestibular Evoked Myogenic Potential (Vemp) is formed by myogenic neurophysiologic responses activated by high-intensity sound stimulation. The response is registered through surface electromyography of the cervical muscles during muscle contraction. The acoustic stimuli activate the saccular macula, the vestibular inferior nerve and the pathways related to the vestibule-spinal descendant nerves. Aim: to describe Vemp parameters in a normal population. Methods: thirty adults, 13 men and 17 women with no otoneurological complaints were selected. The stimuli were 200 tone burst, with a frequency of $1 \mathrm{~Hz}$ and intensity of $118 \mathrm{~dB} \mathrm{Na}$, band-pass filter ranging from $10 \mathrm{~Hz}$ to $1500 \mathrm{~Hz}$. The first potential biphasic P13-N23 wave was analyzed. Results: no significant difference was observed between the sides of stimulation in terms of latency and amplitude. However, a statistically significant difference was found for amplitude between genders. Conclusion: Vemp demonstrated to be a reliable instrument in the clinical assessment of the vestibular function.
\end{abstract}

Key Words: Vestibular Function Tests; Evaluation; Standards.

\section{Resumo}

Tema: o Potencial Evocado Miogênico Vestibular (Vemp) é formado por respostas miogênicas ativadas por estimulação sonora de alta intensidade. Essas respostas são registradas por eletromiografia de superfície sobre a musculatura cervical na presença de contração muscular, ativando a mácula, o nervo vestibular inferior e as vias vestíbulo-espinhais descendentes. Objetivo: descrever as respostas evocadas do Vemp em uma população normal. Método: selecionaram-se 30 sujeitos adultos, sendo 13 homens e 17 mulheres, sem queixas otoneurológicas. Utilizou-se 200 estímulos tone burst com freqüência de $1 \mathrm{~Hz}$ e intensidade de $118 \mathrm{~dB} \mathrm{Na}$, filtro passa-banda de $10 \mathrm{~Hz}$ a $1500 \mathrm{~Hz}$. Os traçados obtidos foram analisados em relação ao primeiro potencial bifásico composto por P13 e N23. Resultados: não houve diferença estatisticamente significativa entre o lado da estimulação em relação a latência e amplitude, porém foi encontrada diferença estatisticamente significativa em relação à amplitude do potencial entre os sexos. Conclusão: Vemp demonstrou ser uma ferramenta confiável na avaliação da função vestibular.

Palavras-Chave: Vestibular; Potencial; Avaliação.

\author{
****Trabalho Realizado no Hospital \\ das Clínicas da Universidade Federal \\ de Minas Gerais. Agências de \\ Financiamento: CAPES, Fapemig, \\ CNPq. \\ Artigo Original de Pesquisa \\ Artigo Submetido a Avaliação por Pares \\ Conflito de Interesse: não \\ Recebido em 27.03.2008. \\ Revisado em 15.06.2008; 29.07.2008. \\ Aceito para Publicação em 21.10.2008.
}




\section{Introduction}

Vestibular Evoked Myogenic Potential (VEMP) assesses muscle response stemming from auditory stimulation. The neural response is a reflex arc of three neurons involving the inner ear, encephalic trunk and vestibulospinal pathway. This reflex arc is involved in the maintenance of body equilibrium. 1

VEMP is formed by myogenic responses activated through sound or galvanic stimulation and recorded by surface electromyography. The course of the potential is the saccular macula, lower vestibular nerveo, lateral vestibular nucleus, descending vestibulospinal pathways and motoneurons of the ipsilateral sternocleidomastoid (SCM) muscle.2 Auditory stimulation with highintensity sounds is the most often employed method, with the response captured in the cervical musculature during muscle contraction.2,3

Electromyographic waves from the recording of the potential are normally defined by the following characteristics:

. latency (time elapsed from acoustic stimulation until the appearance of the most positive or negative value of the waves);

. wave morphology;

. Peak-to-peak amplitude or difference in values between the most positive point of a wave and the most negative point of another. 4

The line traced by VEMP with sound stimulation is made up of two biphasic wave complexes. The first biphasic potential has a positive peak $(\mathrm{P})$ with a mean latency of 13 milliseconds (ms), followed by a negative peak $(\mathrm{N})$ with a mean latency of $23 \mathrm{~ms}$, denominated P13N23 or P14-N21 or P1-N2 (FIGURE 1).2-6

The amplitude of the potential reflects the magnitude of the muscle reflex.8 However, as there is considerable individual variation in the magnitude of this response stemming from intraindividual variations in muscle mass and tone, the asymmetry index of the response is used.8-10 This index compares the affect of muscle tone from one side to the other and is calculated by the inter-aural difference in amplitude of the response, measured by the mean response of each patient.9,10.

The asymmetry index varies between studies and is considered non-significant when the difference between muscle contractions is less than $34.0 \%$ to $47.4 \%$, after the calculation of the equations.8-11.

VEMP has a number of advantages: It is an objective, non-invasive, low-cost, quick exam that is easy to execute, with no discomfort for the individual being evaluated 2,12 .

The exam records the overlapping of neural responses to a muscle potential triggered by the vestibulospinal reflex. As VEMP assesses the final reflex, it therefore does not serve for topographic diagnosis, but either confirms or discards the degree to which the involved pathway is compromised 35.

Studying VEMP as a complementary exam to otoneurological assessment has stimulated a number of authors to investigate and confirm the peripheral receptor and neural pathways involved in the formation of this potential and its clinical applications as well as the stimulation and recording variables and parameters that exercise an influence over the results.

An increasing number of studies on this subject have been published in recent years. For the clinical application of VEMP, it is necessary for the investigation method to have standardized parameters 2,4,7,9,13-16.

The aim of the present study was to determine normality parameters in responses evoked by VEMP in a normal population from the otoneurological standpoint.

\section{Methods}

Participants

Male and female adults with no ringing in the ears, dizziness or hearing loss were included in the study. Individuals with any type middle ear abnormality, tympanic membrane abnormality or deformity in the outer ear conduit (factors that would negatively affect the conduction of sound stimulation) and/or the impossibility of cervical rotation (implying abnormalities in the amplitude of the potential) were excluded.

Thirty individual (13 men and 17 women) were submitted to VEMP. Age ranged from 23 to 65 years, with a mean age of 35.24 years. Only one participant was over 60 years of age.

\section{Materials}

VEMP was performed in an acoustically controlled environment using equipment from BIOLOGIC Systems. Acoustic stimuli were presented through headphones (AUDIOPHONES brand), employing the rarefied tone burst.15,17,18 The stimulus was presented to one ear at a time by the 
computer in a random fashion at an intensity of 118 $\mathrm{dB}$, as the excitability threshold of the saccular macula by sound is high (around $60 \mathrm{~dB}$ NA).19 A $10-\mathrm{Hz}$ to $1500-\mathrm{Hz}$ band-pass filter was used.20 To obtain each wave representation, 200 stimuli were presented at a frequency of $1 \mathrm{~Hz} .5,17$ The analysis window was $60 \mathrm{~ms}$. Each individual was submitted to at least two stimulations on each side to determine the replication of the potential. Impedance values were determined prior to each recording and were expected to be below $5 \mathrm{KVhms.}$

Following friction of the skin with an appropriate material, surface electrodes $1 \mathrm{~cm}$ in diameter (BIOLOGIC Systems) were used to capture the signals. The electrodes were placed on the following positions: active - on the upper part of the SCM muscle; reference - on the sternum; and ground on the forehead.3,5 A small amount of electrolytic material was applied to the surface of the electrodes in order to optimize the recording. The electrodes were then attached to the skin with adhesive tape. In order for SCM muscle contraction to be objectively monitored, a 4-channel electromyographic surface apparatus (EMG System) was used, with the Root Mean Square of the signal.

Procedures

The study received approval from the Research Ethics committee of the Universidade Federal de Minas Gerais (Brazil) under Process $n^{\circ}$ 266/05. All participants signed terms of informed consent prior to participation in the study.
During the exam, the subject was instructed to sit in a chair and maintain the rotation of the head to the opposite side of the ear to be stimulated, thereby provoking contraction of the SCM muscle.11,17,18 Contraction of the cervical musculature was maintained at a relatively constant level of 50 to 200 microvolts (mV).8,17 However, patient cooperation in maintaining the same position was equally important throughout the test.

\section{Results}

The Student's t-test was used for the analysis of the results, adopting a 5\% level of significance $(\mathrm{p}<0.05)$. Analysis regarded the P13 and N23 latencies and amplitudes and the asymmetry index of the amplitude. The variables referring to the VEMP responses were compared with regard to the side assessed (TABLE 1) and gender (TABLE 2).

Comparing the right and left sides, there were no statistically significant differences regarding P13 and N23 latency or P13-N23 amplitude values. Comparing genders, no expressive difference was found with regard to the latency of the waves, but there was a statistically significant difference regarding the amplitude value, with greater values found in the men than the women $(p=0.00)$. The value of the asymmetry index ranged from $0.2 \%$ to $26.4 \%$. Electromyographic muscle contraction responses ranged from 53 to 167 ?V. It should be pointed out that the only participant over 60 years of age had similar responses to the others and was therefore not excluded from the study. 
FIGURE 1. Line traced by VEMP recording: formation of biphasic P13 and N23 potential.

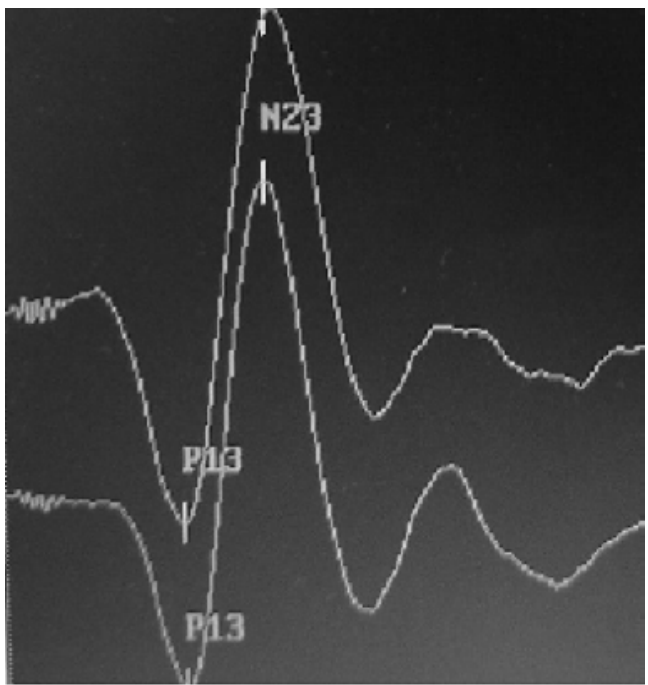

TABLE 1. Comparison of P13 and N23 latencies (ms) an d amplitude of the P13-N23 wave $(\mu \mathrm{V})$ for the right and left ear.

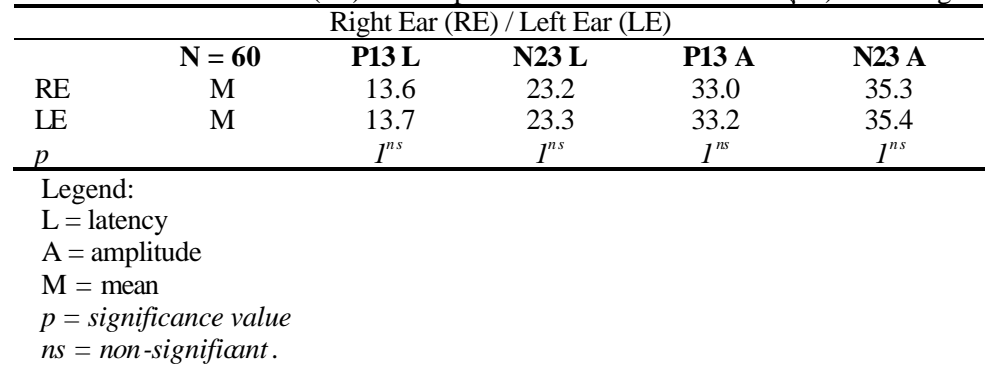

TABLE 2. Comparison of P13 and N23 latencies (ms) and amplitude of the P13 -N23 wave $(\mu \mathrm{V})$ and asymmetry index for both genders.

\begin{tabular}{|c|c|c|c|c|c|c|}
\hline \multicolumn{7}{|c|}{ Men (?) / Women (?) } \\
\hline & $\mathbf{N}=\mathbf{3 0}$ & P13 L & N23 L & P13 A & N23 A & AI \\
\hline$? \mathrm{~N}=13$ & $\mathrm{M}$ & 13.6 & 23.1 & 43.4 & 47.9 & $5 \%$ \\
\hline$? \mathrm{~N}=17$ & M & 13.6 & 23.3 & 25.6 & 25.2 & $1 \%$ \\
\hline$P$ & & $1^{n s}$ & $l^{n s}$ & 0.00 & 0.00 & \\
\hline
\end{tabular}

\section{Discussion}

The protocol for the present study on VEMP was determined based on studies addressing the normalization of responses in normal subjects. Regarding the acoustic stimulus, a variety of frequencies have been described. However, frequencies equal to or below $5 \mathrm{~Hz}$ are the most often used and evoke more homogeneous, constant responses..5,8,9,21 Response characteristics depend upon the type of stimulus administered. According to a number of studies, vestibular myogenic potentials evoked by tone bursts require a lower stimulation threshold than evocation by clicks.15,22
Placement of the electrodes on the surface of the SCM muscle has been the most often employed method, for, according to the literature, the responses are more consistent and homogeneous; it is also a more practical method for the examiner and more comfortable for the patient.4,9,18 Regarding the effect of placing the electrode on the SCM muscle for VEMP, studies have suggested that the middle portion of this muscle is the best site for recording the response.21,23 A number of studies have demonstrated that the position that promotes the greatest activation of the SCM muscle is the maximum lateral rotation of the head, with the individual seated.11,17,18 
The determination of the band-pass filter - which involves the selection of signals from a band of frequencies, thereby blocking signals from frequencies above and below the limits of this band - was based on previous studies, which found greater sharpness and, consequently, precision in the marking of the peaks in the potentials evoked.24

Regarding the results of the VEMP, all participants had responses in both ears, indicating the integrity of the saccular macula, lower vestibular nerve, vestibular nucleus, vestibularspinal pathways and effector muscle.2-7 Thus, the wave representations obtained in the present study were analyzed with regard to the first biphasic potential composed of P13 and N23, which corresponds to the reflex evoked by the acoustic stimulation of the saccular macula.2

The analysis of the VEMP responses in this sample of otoneurologically normal individuals revealed similar results to those described in other studies, when comparing latency and amplitude values.8-11 The amplitude response may be influenced by the degree of muscle contraction.16,23 This may be the reason for which higher values were obtained for male individuals, considering the difference in muscle tone when compared to the

\section{References}

1. Versino M, Colnaghi S, Callieco R, Bergamaschi R, Romani A, Cosi V. Vestibular evoked myogenic potentials in multiple sclerosis patients. Clin Neurophysiol. 2002;113(9):14649.

2. Halmagyi GM, Colebatch JG, Curthoys IS. New tests of vestibular function. Baillière's Clinical Neurology. 1994;3(3):485-500.

3. Colebatch JG, Halmagyi GM. Vestibular evoked potentials in human neck muscles before and after unilateral vestibular deafferentation. Neurology. 1992;42(8):1635-6.

4. Guillén VP, García EG, Piñero AG, Rey APD, Pérez CM. Potencial vestibular miogénico evocado: un aporte al conocimiento de la fisiología y patología vestibular. Patrones cuantitavos en la población normal. Acta Otorrinolaringol Esp. 2005;56:349-53.

5. Colebatch JG, Rothwell JC, Bronstein A H Ludman H. Click-evoked vestibular activation in the Tullio phenomenon. J. Neurol. Neurosurg. Psychiatry. 1994;57(12):1538-40.

6. Shimizu K, Murofushi T, Sakurai M, Halmagyu M. Vestibular evoked myogenic potentials in multiple sclerosis. J Neurol Neurosurg Psychiatry. 2000;69(2):276-7.

7. Yokota J. Click-evoked myogenic potential as a new diagnostic tool for the vestibular disorders. No To Shinkei. 2000;52(8):691-9. female gender. Thus, when referring to amplitude value, the asymmetry percentage obtained from the comparison of the response amplitude on the right and left sides in the same subject was considered. The calculation of the asymmetry index indicated variation ranging from 0.2 to $26.4 \%$, which, based on previously published normality data, is considered adequate. $8-11$

The findings on the participant over 60 years of age should be discussed, as previous studies have found significant differences in the VEMP amplitude values in elderly individuals. These differences occur due to the ageing of the saccular macula and muscle fibers. 10 However, this was not found in the present study.

\section{Conclusion}

The promising tendencies indicated by new investigations addressing VEMP lead to the belief that, when used in a coherent fashion, important results can be achieved for diagnostic studies.

It is important to stress that even with its simplied low-cost recording methodology, it is necessary that this exam have standardized parameters for its clinical application.
8. Akin FW, Murnane OD, Panus PC, et al. The influence of voluntary tonic EMG level on the vestibular-evoked myogenic potential. J Rehabil Res Dev. 2004;41(3):47380 .

9. Ferber-Viart C, Duclaux R, Colleaux B, Dubreuil C. Myogenic vestibular evoked potentials in normal subjects: comparison between responses obtained on sternomastoid and trapezius muscles. Acta Otolaryngol. 1997;117(4):47281 .

10. de Waele C, Huy PT, Diard JP, Freyss G, Vidal PP. Saccular dysfunction in Ménière's disease. Am J Otol. 1999;20(2):223-32.

11. Murofushi T, Matsuzaki M, Mizuno M. Vestibular evoked myogenic potentials in patients with acoustic neuromas. Arch Otolaryngol Head Neck Surg. 1998;124(5):509-12.

12. Colebatch JG. Vestibular evoked potentials. Curr Opin Neurol. 2001;14(1):21-6.

13. Ochi K. Age-related changes in the vestibularevoked myogenic potentials. Otolaringol Head Neck Surg. $2003 ; 129(6): 655-9$.

14. Su H, Huang T, Young Y, Cheng P. Aging effect on vestibular evoked myogenic potential. Otol Neurotol. 2004;25(6):977-80. 
15. Welgampola MS, Colebatch, JG. Characteristics and clinical applications of vestibular-evoked myogenic potentials. Neurology. 2005;64(10):1682-8.

16. Sheean GL, Lim CL, Yiannikas C. Some nonpathological variables affecting the vestibular evoked potential. Aust NZJ Med. 1993;23:572.

17. Wu CH, Young YH, Murofushi T. Tone burst-evoked myogenic potentials in human neck flexor and extensor. Acta Otolaryngol. 1999;119(7):741-4.

18. Murofushi T, Matsuzaki M, Wu CH. Short tone burstevoked myogenic potentials on the sternocleidomastoid muscle: are these potentials also of vestibular origin? Arch Otolaryngol Head Neck Surg.1999;125(6):660-4.

19. Murofushi T, Curthoys IS, Topple AN, Colebatch JG, Halmagyi G M. Responses of guinea pig primary vestibular neurons to clicks. Exp Brain Res.1995;103(1):174-8.
20. Sartucci F, Logi F. Vestibular-evoked myogenic potentials: a method to assess vestibulo-spinal conduction in multiple sclerosis patients. Brain Res Bull. 2002;59(1):5963.

21. Sheykholeslami K, Kaga K, Murofushi T, Hughes DW. Vestibular function in auditory neuropathy. Acta Otolaryngol. 2000;120:849-54.

22. Akin FW, Murnane OD, Proffitt TM. The effects of click and tone-burst stimulus parameters on the vestibular evoked myogenic potential (VEMP). I Am Acad Audiol. 2003;14(9):500-9.

23. Lim CL, Clouston P, Sheean G, Yiannikos C. The influence of voluntary EMG activity and click intensity on the vestibular click evoked myogenic potential. Muscle Nerve. 1995;18(10):1210-3.

24. Kavanagh KT, Harker LA, Tyler RS. Auditory brainstem and middle latency responses. Ann Otol Rhinol Laryngol. 1984; 93(1):2-12. 